\title{
Use of biomaterials in the surgical regenerative treatment of peri-implantitis:
}

\section{systematic review}

\section{A utilização de biomateriais no tratamento cirúrgico regenerativo da peri-implantite: revisão sistemática}

El uso de biomateriales en el tratamiento quirúrgico regenerativo de la periimplantitis: una revisión sistemática

\author{
Juliana Campos Pinheiro \\ ORCID: https://orcid.org/0000-0001-5687-7635 \\ Federal University of Rio Grande do Norte, Brazil \\ E-mail: dra.julianacpinheiro@gmail.com \\ Braz da Fonseca Neto \\ ORCID: https://orcid.org/0000-0002-4338-7925 \\ Federal University of Rio Grande do Norte, Brazil \\ E-mail: brazneto2511@gmail.com \\ Jabes Gennedyr da Cruz Lima \\ ORCID: https://orcid.org/0000-0001-7420-7686 \\ Federal University of Rio Grande do Norte, Brazil \\ E-mail: jabes.gennedyr@hotmail.com \\ Yunes Araújo Silva \\ ORCID: https://orcid.org/0000-0001-7108-430X \\ Potiguar University, Brazil \\ E-mail: yunesaraujo@gmail.com \\ Gabriel Gomes da Silva \\ ORCID: https://orcid.org/0000-0002-1341-7505 \\ Federal University of Rio Grande do Norte, Brazil \\ E-mail: silvagg94@gmail.com \\ Isaac Pessoa Santiago Morais \\ ORCID: https://orcid.org/0000-0001-8738-2352 \\ Federal University of Rio Grande do Norte, Brazil \\ E-mail: isaac_8787@hotmail.com \\ Dennys Ramon de Melo Fernandes Almeida \\ ORCID: https://orcid.org/0000-0002-4686-4379 \\ Federal University of Rio Grande do Norte, Brazil \\ E-mail: dennysfernandes@ymail.com
}

\begin{abstract}
The aim of this study was to review the scientific literature regarding the effectiveness of different biomaterials in the regenerative treatment of peri-implantitis. A systematic literature search was performed in PubMed/Medline, Web of Science, Science Direct, Embase, and the Cochrane Collaboration Library. Studies on the use of biomaterials in the regenerative treatment of peri-implantitis were selected. The search strategy retrieved 253 articles. After selection, six articles met all inclusion criteria and were included in the present systematic review. The studies showed that an initial therapeutic approach consisting of plaque control and implant surface decontamination and subsequent surgery for biomaterial placement were essential for the successful regenerative treatment of peri-implantitis defects. Analysis of all biomaterials used in surgical regenerative treatment showed that bovine bone grafts provided superior outcomes in terms of new bone formation compared to autogenous grafts and nanocrystalline hydroxyapatite. It is important to note that porous titanium granules have emerged as a promising biomaterial for the regenerative treatment of periimplantitis. In conclusion, biomaterials are promising for the treatment of peri-implant bone defects and the number of in silico biomaterials that can provide treatment of excellence to patients with this condition is expected to increase in the near future.
\end{abstract}

Keywords: Dentistry; Dental implants; Osseointegration; Peri-implantitis; Bone regeneration; Biomaterials.

\section{Resumo}

O objetivo deste estudo foi revisar a literatura científica a respeito da eficácia de diferentes biomateriais no tratamento regenerativo da peri-implantite. Uma busca sistemática da literatura foi realizada no PubMed / Medline, Web of Science, Science Direct, Embase e na Cochrane Collaboration Library. Foram selecionados estudos sobre a utilização 
de biomateriais no tratamento regenerativo da peri-implantite. A estratégia de busca recuperou 253 artigos. Após a seleção, seis artigos atenderam a todos os critérios de inclusão e foram incluídos na presente revisão sistemática. Os estudos mostraram que uma abordagem terapêutica inicial consistindo no controle da placa e descontaminação da superfície do implante e subsequente cirurgia para colocação de biomaterial foram essenciais para o sucesso do tratamento regenerativo dos defeitos da peri-implantite. A análise de todos os biomateriais utilizados no tratamento cirúrgico regenerativo mostrou que os enxertos ósseos bovinos proporcionaram resultados superiores em termos de neoformação óssea em comparação com os enxertos autógenos e hidroxiapatita nanocristalina. É importante notar que os grânulos de titânio poroso surgiram como um biomaterial promissor para o tratamento regenerativo da periimplantite. Em conclusão, os biomateriais são promissores para o tratamento de defeitos ósseos peri-implantares e espera-se que aumente no futuro próximo o número de biomateriais in silico que podem proporcionar tratamento de excelência a pacientes com esta patologia.

Palavras-chave: Odontologia; Implantes dentários; Osseointegração; Peri-implantite; Regeneração óssea; Biomateriais.

\section{Resumen}

El objetivo de este estudio fue revisar la literatura científica sobre la efectividad de diferentes biomateriales en el tratamiento regenerativo de la periimplantitis. Se realizó una búsqueda bibliográfica sistemática en PubMed / Medline, Web of Science, Science Direct, Embase y Cochrane Collaboration Library. Se seleccionaron estudios sobre el uso de biomateriales en el tratamiento regenerativo de la periimplantitis. La estrategia de búsqueda recuperó 253 artículos. Después de la selección, seis artículos cumplieron con todos los criterios de inclusión y se incluyeron en la presente revisión sistemática. Los estudios demostraron que un enfoque terapéutico inicial consistía en el control de la placa y la descontaminación de la superficie del implante y la cirugía posterior para la colocación de biomaterial era esencial para el tratamiento regenerativo exitoso de los defectos de periimplantitis. El análisis de todos los biomateriales utilizados en el tratamiento regenerativo mostró que los injertos óseos bovinos proporcionaron resultados superiores en términos de formación de hueso nuevo en comparación con los injertos autógenos y la hidroxiapatita nanocristalina. Es importante señalar que los gránulos de titanio poroso han surgido como un biomaterial prometedor para el tratamiento regenerativo de la periimplantitis. En conclusión, los biomateriales son prometedores para el tratamiento de defectos óseos periimplantarios y se espera que aumente en un futuro próximo el número de biomateriales in silico que pueden proporcionar un tratamiento de excelencia para pacientes con esta afección.

Palabras clave: Odontología; Implantes dentales; Osteointegración; Periimplantitis; Regeneración ósea; Biomateriales.

\section{Introduction}

Rehabilitation treatment using osseointegrated implants in partially or totally edentulous patients has shown a high success rate in dentistry (Rotenberg, 2016). However, the durability of implant osseointegration depends on the preservation and health of the peri-implant tissues. In stable implants, the commonly found average probing depth is $3 \mathrm{~mm}$ (Arab, 2016).

The inflammatory reactions that occur in the mucosa surrounding osseointegrated implants are the result of an imbalance between host defenses and bacterial aggression (Alqahtani, 2019). Like periodontitis, peri-implantitis is a destructive inflammatory process that affects both the soft and hard tissues around the dental implant. Tissue inflammation, bacterial plaque, suppuration, bleeding, and an increase in probing depth are commonly observed symptoms (Heitz-Mayfield, 2014; Mccrea, 2014; Kim, 2019).

Similar to what is observed in periodontal tissues, the trigger of peri-implant diseases is the bacterial biofilm, which mainly consists of periodontopathogenic bacteria. It is important to note that factors associated with the development of periimplantitis such as mechanical overload of the prosthesis on the implant and smoking can enhance the destruction of periimplant tissues, jeopardizing not only osseointegration but also implant longevity (AAP, 2013; Noriko, 2014; Kim, 2019; Alqahtani, 2019).

The first approach in the treatment of peri-implantitis consists of decontamination of the implant surface by mechanical and/or chemical debridement, in which all granulation tissue is removed. Implantoplasty might be necessary in some cases. This procedure consists of smoothening the threads of exposed implants with drills in order to prevent biofilm retention at the site (Faggion, 2014). In addition to these approaches, the use of tissue regeneration in implantology has been 
widely discussed considering that the reversal of bone height loss is not possible, with interventions in peri-implant tissues only interrupting the deleterious effects of the active biofilm (Lopes, 2018). Within this context, grafts using natural or synthetic mineral tissue have been applied to reestablish the function of compromised implants, thus avoiding failures. The necessary properties of such biomaterials include the capacity to promote osteogenesis, osteoinduction, and osteoconduction (Aghazadeh, 2012).

The aim of surgical regenerative treatment of peri-implantitis is to promote the formation of new bone at a site previously affected by bacterial infection. The presence of healthy bone tissue around osseointegrated implants is of the utmost importance for the maintenance of adequate tissue dimensions, preventing gingival recession and ensuring the long-term success of rehabilitation treatment. Regenerative techniques utilize different osteogenic, osteoinductive and osteoconductive biomaterials. The most common are autogenous and xenogenic bone. These grafts are covered with biological membranes during the surgical procedures, which serve as barriers to favor bone neoformation (Wiltfang, 2012; Roos-Jansaaker, 2014).

The current literature shows that therapeutic approaches to eliminate bacterial infection combined with surgical regenerative treatments provide promising long-term outcomes in terms of dental implant survival. Therefore, the aim of this systematic review was to evaluate the effectiveness of different biomaterials in the regenerative treatment of peri-implantitis.

\section{Methodology}

\section{Search strategy}

This systematic review was registered in PROSPERO 2020 under protocol $\mathrm{n}^{0}$ CDR420202683 and conducted following the PRISMA statement (Moher, 2009). as shown in Figure 1. A literature search was performed in the following electronic databases without language or publication date restrictions: PubMed/Medline, Web of Science, Science Direct, Embase, and the Cochrane Collaboration Library. All steps of the study were evaluated by a reviewer with experience in the elaboration of systematic review protocols (JCP). The search strategy was based on combinations of the following keywords ("Bone Regeneration" [MeSH] AND "Biomaterials" [MeSH] AND "Peri-implantitis" [MeSH] AND "Treatment" [MeSH] AND "Outcome" $[\mathrm{MeSH}])$. In addition, the references of the articles were searched manually for the potential inclusion of studies in the systematic review. 
Figure 1. PRISMA flow diagram of screened studies.

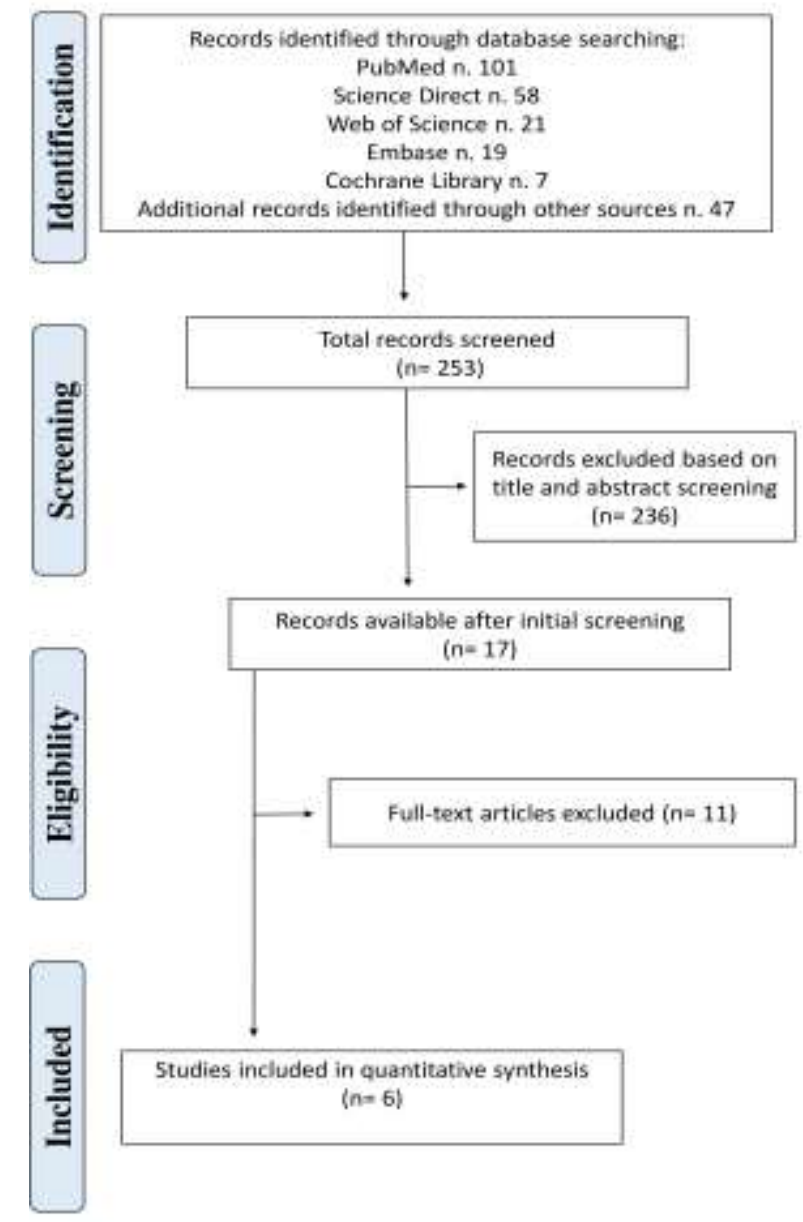

Source: Authors.

\section{Selection of studies}

For this search, the PICO model was used to establish the following key research question of the systematic review: Is the use of biomaterials effective in the surgical regenerative treatment of peri-implantitis? The studies were eligible independent of language or publication year. Clinical studies that used biomaterials for the treatment of peri-implantitis and followed up the patients for the analysis of outcomes (cure/regression of peri-implantitis) were included. Experimental animal studies, in vitro studies, review articles, case reports, and studies that did not use biomaterials for peri-implantitis treatment were excluded. Articles that did not meet the eligibility criteria and duplicate articles were removed. In a first step, articles were selected based on the analysis of titles and abstracts. Next, all studies whose titles or abstracts were considered relevant to the topic were obtained and their full-text was read.

Finally, the articles analyzed and selected by the evaluator were included in the data systematization. A reference management software (EndNote, Philadelphia, Pennsylvania, USA) was used for control of the articles analyzed and for duplicate removal. The following information was extracted from the selected studies: authors, year of publication, country, number of cases diagnosed with peri-implantitis, treatment protocol, biomaterial used, follow-up time, conclusions, and relevant outcomes.

\section{Risk of bias of the included studies}

Two reviewers (JCP and GGS) evaluated the risk of bias of the individual studies independently. The approach we 
used for assessing risk of bias in included studies was recommended by Cochrane reviews. According to Cochrane handbook a bias is a systematic error in results or inferences, which means that multiple replication of the same study would reach the wrong answer on average (Higgins, 2011). The biases that were considered were as follows: (1) random sequence generation (selection bias), (2) allocation concealment (selection bias), (3) blinding of participants and personnel (performance bias), (4) blinding of Outcome assessment (detection bias), (5) incomplete outcome data (attrition bias), (6) selective reporting (reporting bias).

\section{Results}

\section{Selection of studies}

The search strategy elaborated in this systematic review retrieved 253 studies from the databases evaluated. After screening the titles and abstracts, 17 studies were considered potentially eligible and two independent evaluators (JCP and GGS) read the full text of the articles. After analysis, six articles published between 2006 and 2018 met all inclusion criteria and were selected for this systematic review.

\section{Quality of included studies}

The tests differed in relation to the types of biomaterials used to promote bone regeneration in peri-implant injuries. The follow-up time in the selected studies also differed. The risk of bias in the included studies was considered low and was performed as shown in Figure 2.

Figure 2. Risk of bias in the included studies.

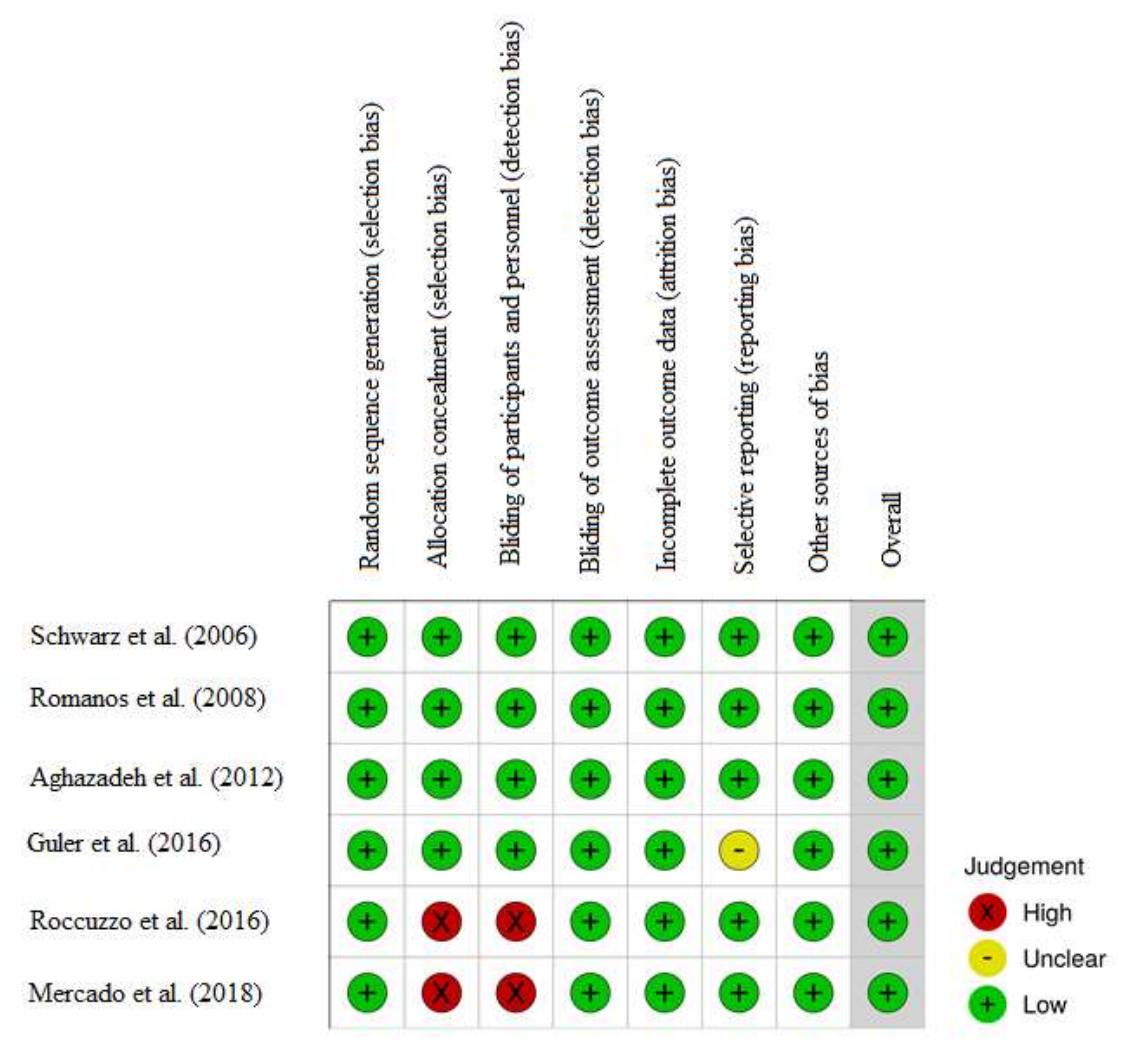

Source: Authors. 


\section{Characteristics of the studies}

Regarding methodological characteristics, the number of patients ranged from 15 to 75 , with a mean of 35.1 participants per study. The total sample size was 211 patients. Only randomized controlled clinical trials that evaluated the effectiveness of biomaterials in the regenerative treatment of peri-implantitis were selected. The samples consisted of adult patients in their fourth or fifth decade of life, with a mean age of approximately 43.2 years. Among the selected articles, only one did not report the male/female ratio of the participants. Considering the total sample, there were $74.7 \%$ female patients versus only $25.2 \%$ male patients (Table 1 ).

Table 1. Methodological aspects and main results of the selected studies $(\mathrm{n}=6)$.

\begin{tabular}{|c|c|c|c|c|}
\hline Author (year) & Country & $\begin{array}{c}\mathrm{N}^{\circ} \text { de pacientes incluídos } \\
\text { na Análise }\end{array}$ & Genre & Age (average) \\
\hline $\begin{array}{c}\text { Aghazadeh et } \\
\text { al. }{ }^{11}\end{array}$ & Sweden & 45 & Uninformed & Uninformed \\
\hline Schwarz et al. ${ }^{16}$ & Germany & 22 & $\begin{array}{l}8 \mathrm{M} \\
14 \mathrm{~F}\end{array}$ & 54.4 \\
\hline Romanos et al. ${ }^{17}$ & Germany & 15 & $\begin{array}{l}5 \mathrm{M} \\
10 \mathrm{~F}\end{array}$ & 57.2 \\
\hline Guler et al. ${ }^{18}$ & Turkey & 24 & $\begin{array}{l}9 \mathrm{M} \\
15 \mathrm{~F}\end{array}$ & 45.3 \\
\hline Roccuzzo et al. ${ }^{19}$ & Italy & 75 & $\begin{array}{l}39 \mathrm{M} \\
36 \mathrm{~F}\end{array}$ & 57.8 \\
\hline Mercado et al. ${ }^{20}$ & Australia & 30 & $\begin{array}{l}10 \mathrm{M} \\
20 \mathrm{~F}\end{array}$ & 44.9 \\
\hline
\end{tabular}

Legends: M, Male; F, Female. Source: Pinheiro et al. (2021).

\section{Clinical procedures performed and types of biomaterials used}

In the study of Schwarz (2006), the patients were divided into two groups of 11 subjects each. Both groups were first submitted to bacterial plaque control combined with decontamination of the dental implant surfaces using plastic curettes (Straumann; Waldenburg, Switzerland), followed by irrigation of the peri-implant pockets with $0.2 \%$ chlorhexidine digluconate (Corsodyl, GlaxoSmithKline, London, United Kingdom). Next, the implant surface was decontaminated by applying $0.2 \%$ chlorhexidine gel (Corsodyls Gel, GlaxoSmithKline Consumer Healthcare, Bühl, Germany) to the subgingival areas. The biomaterials used for promoting bone regeneration were nanocrystalline hydroxyapatite (Ostim, Heraeus, Hanau, Germany) and bovine bone graft (Bio-Oss, Geistlich Pharma, Wolhusen, Switzerland). For placement of the different biomaterials, an access flap was created in each group under general anesthesia and the granulation tissue was completely removed with plastic curettes (Straumann, Waldenburg, Switzerland). After cleaning the site, the exposed implants and bone surfaces were washed with sterile saline. After grafting, a porcine bioabsorbable collagen membrane (BioGides, Geistlich Pharma, Wolhusen, Switzerland) was adapted to the bone defect sites to ensure stability of the biomaterial. The flaps were then repositioned and sutured. No postoperative complications were observed (Table 2).

Romanos (2008) performed bacterial plaque control and decontamination of the implant surfaces prior to the regenerative procedure in all patients. First, a mucoperiosteal flap was created under anesthesia to facilitate exposure of the peri-implant bone defects. The granulation tissue was completely removed with titanium curettes. Next, a CO2 laser (SC 20, Weil Dental or Smart US-20D, DEKA, Florence, Italy.) was applied to the implant surface at an energy of $2.84 \pm 0.83$ Watts for 1 minute. Eight patients received regenerative treatment using autogenous bone previously removed from the regions of the mandibular mentum, mandibular ramus and maxillary tuberosity. The remaining patients were treated with bovine bone graft 
(BioOss, Osteohealth, New York, USA) in the peri-implant defects. All grafted sites were covered with a collagen membrane (BioGide, Osteohealth, New York, USA) fixed with titanium pins (FRIOS Membrane Tacks, Dentsply Friadent, Germany). The mucoperiosteal flaps were sutured and no postoperative complications were observed (Table 2).

In the study of Aghazadeh (2012), all patients received oral hygiene instructions for bacterial plaque control and the implant surfaces were cleaned with manual instruments before placement of the biomaterials. A mucoperiosteal flap was created under anesthesia to access the peri-implant defects and granulation tissue was completely removed with titanium curettes (Implant curettes, Deppeler SA, Rolle, Switzerland). The implants surfaces were cleaned with 3\% hydrogen peroxide for 1 minute and rinsed with saline. The patients were divided into two groups and treated with different biomaterials: group 1 received an autogenous bone graft collected from the mandibular ramus and group 2 received a bovine bone graft (Bio-Oss, Geistlich Pharma, Wolhusen, Switzerland) combined with a resorbable collagen membrane (OsseoGuard, Biomet 3i Inc, Florida, USA) to protect the graft site. The mucoperiosteal flaps were sutured and no postoperative complications were observed (Table 2).

Guler (2017) divided their patients into two groups. All patients received oral hygiene instructions for bacterial plaque control and were submitted to decontamination of the dental implant surface using a rotating titanium brush (TiBrush, Straumann, Waldenburg, Switzerland). For regenerative treatment of peri-implant defects, groups 1 received porous titanium granules (Natix, Tigran Technologies AB, Malmö, Sweden) covered with a platelet-rich fibrin membrane obtained by centrifugation of the patient's own blood sample. Group 2 received bovine bone graft (Gen-Os, OsteoBiol, Tecnoss Dental, Torino, Italy), which was covered with a collagen membrane (Evolution, OsteoBiol, Tecnoss Dental, Torino, Italy) and platelet-rich fibrin membrane. No postoperative complications were observed (Table 2).

In the study of Roccuzzo (2016), all patients received oral hygiene instructions for bacterial plaque control. The implant surfaces were decontaminated and granulation tissue was completely removed with titanium curettes. The same implants received another decontamination treatment by cleaning with a titanium brush (Tigran Peri-brush, Tigran Technologies AB, Malmö, Sweden) under irrigation with sterile saline. In addition, 24\% EDTA (Prefgel, Straumann, Waldenburg, Switzerland) and 1\% chlorhexidine gel (Corsodyl, GlaxoSmithKline, London, United Kingdom) were applied to the implant surfaces. The bone defects of 75 patients were filled with deproteinized bovine bone mineral with $10 \%$ collagen (Bio-Oss Collagen, Geistlich Pharma, Wolhusen, Switzerland). No postoperative complications were observed (Table 2).

Mercado (2018) provided oral hygiene instructions for bacterial plaque control and decontaminated the dental implant surfaces in all patients included in the study. First, mechanical debridement of the implant surfaces was performed, completely removing the granulation tissue, and the surface of the exposed implant was decontaminated with 24\% EDTA (Prefgel, Straumann, Waldenburg, Switzerland). The peri-implant bone defects of 30 patients were filled with a combined mixture of deproteinized bovine bone mineral with $10 \%$ collagen (Bio-Oss, Collagen, Geistlich Pharma, Wolhusen, Switzerland) and enamel matrix protein derivative (EMDOGAIN, Straumann, Waldenburg, Switzerland). All patients received a postoperative kit containing mouth rinse with $0.12 \%$ chlorhexidine digluconate to be used twice a day in the first week and $0.12 \%$ chlorhexidine gel applied to the treated area in the second and third week. No postoperative complications were observed (Table 2).

\section{Main outcomes and mean patient follow-up after regenerative treatment of peri-implant bone defects}

In the study of Schwarz (2006), both the group undergoing regenerative treatment with nanocrystalline hydroxyapatite (Ostim, Heraeus, Hanau, Germany) and the group receiving bovine bone graft (Bio-Oss, Geistlich Pharma, Wolhusen, Switzerland) exhibited a reduction of radiolucency inside the peri-implant bone defects after a mean follow-up period of 6 months. Neoformation of dense bone tissue was observed, whose structure resembled that of adjacent alveolar bone. However, 
the biomaterial derived from bovine medullary bone resulted in better bone gain compared to nanocrystalline hydroxyapatite. Romanos (2008) followed up patients submitted to regenerative treatment of peri-implant bone defects using bovine bone graft (BioOss, Osteohealth, New York, USA) and autogenous graft for 27 months. The authors observed better outcomes when CO2 laser implant surface decontamination (SC 20, Weil Dental or Smart US-20D, DEKA, Florence, Italy) was combined with the bovine bone graft compared to the autogenous graft. Radiographically, bone neoformation was observed at the site and gain in clinical attachment (Table 2).

Aghazadeh (2012), after 12 months of follow-up of patients submitted to regenerative treatment of peri-implantitis using different biomaterials, observed that the bovine bone graft (Bio-Oss, Geistlich Pharma, Wolhusen, Switzerland) resulted in higher bone-defect fill than autogenous bone grafting. These results were confirmed by the radiographic findings. Guler (2017) used porous titanium granules (Natix ${ }^{\circledR}$, Tigran Technologies AB, Malmö, Sweden) and bovine bone graft (Gen-Os, OsteoBiol, Tecnoss Dental, Torino, Italy) for bone-defect filling. After 6 months of follow-up, the porous titanium granules exhibited better results in the treatment of peri-implant bone defects due to their structure when compared to bovine bone graft. These findings were confirmed by radiographic examination and by a gain in clinical attachment.

Roccuzzo (2016) followed up their patients for 12 months and observed that the use of deproteinized bovine bone mineral with 10\% collagen (Bio-Oss, Geistlich Pharma, Wolhusen, Switzerland) provided satisfactory results in the regenerative treatment of peri-implant lesions. Radiographically, new bone formation and gain in clinical attachment were observed. In the study of Mercado (2018_, the patients were followed up for 36 months. Regenerative treatment of periimplantitis using a combined mixture of deproteinized bovine bone mineral with 10\% collagen (Bio-Oss, Geistlich Pharma, Wolhusen, Switzerland) and enamel matrix derivative (EMDOGAIN, Straumann, Waldenburg, Switzerland) provided positive results, including the formation of new bone at the site of the peri-implant defects.

Table 2. Main results of selected studies $(n=6)$

\begin{tabular}{|c|c|c|c|c|c|}
\hline $\begin{array}{c}\text { Author } \\
\text { (year) }\end{array}$ & $\begin{array}{c}\text { Groups } \\
\text { (patients) }\end{array}$ & Biomaterials used & Procedures performed & $\begin{array}{l}\text { Average } \\
\text { follow-up }\end{array}$ & Main results \\
\hline $\begin{array}{c}\text { Aghazad } \\
\text { eh et } \\
\text { al. }^{11}\end{array}$ & $\begin{array}{l}\text { Group 1: } \\
22 \text { patients } \\
\text { Group 2: } \\
23 \text { patients }\end{array}$ & $\begin{array}{l}\text { Group } 1 \\
\text { Autogenous bone graft. } \\
\text { Group } 2 \\
\text { Bovine bone graft (Bio-Oss, } \\
\text { Geistlich Pharma, Wolhusen, } \\
\text { Switzerland). }\end{array}$ & $\begin{array}{l}\text { Control of bacterial plaque. } \\
\text { Decontamination of dental } \\
\text { implant surfaces. } \\
\text { Application of biomaterials } \\
\text { to bone defects. }\end{array}$ & 12 months & $\begin{array}{l}\text { The bovine bone graft } \\
\text { provided greater filling in } \\
\text { the bone defects when } \\
\text { compared to the } \\
\text { autogenous bone graft. }\end{array}$ \\
\hline $\begin{array}{l}\text { Schwarz } \\
\text { et al. }{ }^{16}\end{array}$ & $\begin{array}{l}\text { Group 1: } \\
11 \text { patients } \\
\text { Group 2: } \\
11 \text { patients }\end{array}$ & $\begin{array}{l}\text { Nanocrystalline hydroxyapatite } \\
\text { (Ostim, Heraeus, Hanau, Germany). } \\
\text { Group } 2 \\
\text { Bovine bone graft (Bio-Oss, } \\
\text { Geistlich Pharma, Wolhusen, } \\
\text { Switzerland). }\end{array}$ & $\begin{array}{l}\text { Control of bacterial plaque. } \\
\text { Decontamination of dental } \\
\text { implant surfaces. } \\
\text { Application of biomaterials } \\
\text { to bone defects. }\end{array}$ & 6 months & $\begin{array}{l}\text { Both groups showed a } \\
\text { decrease in radiolucency } \\
\text { within the peri-implant } \\
\text { defects. However, the } \\
\text { Bovine bone graft showed } \\
\text { a greater gain in } \\
\text { periodontal insertion when } \\
\text { compared to } \\
\text { nanocrystalline } \\
\text { hydroxyapatite. }\end{array}$ \\
\hline
\end{tabular}




\begin{tabular}{|c|c|c|c|c|c|}
\hline $\begin{array}{l}\text { Romano } \\
\text { s et al. }{ }^{17}\end{array}$ & $\begin{array}{l}\text { Group 1: } 8 \\
\text { patients } \\
\begin{array}{l}\text { Group 2: } 7 \\
\text { patients }\end{array}\end{array}$ & $\begin{array}{l}\text { Group } 1 \\
\text { Autogenous bone graft. } \\
\text { Group } 2 \\
\text { Bovine bone graft (BioOss, } \\
\text { Osteohealth, New York, USA). }\end{array}$ & $\begin{array}{l}\text { Control of bacterial plaque. } \\
\text { Decontamination of dental } \\
\text { implant surfaces using CO2 } \\
\text { laser application (SC 20, } \\
\text { Weil Dental or Smart US- } \\
\text { 20D,DEKA, Florence, } \\
\text { Italy). } \\
\text { Application of biomaterials } \\
\text { to bone defects. }\end{array}$ & 27 months & $\begin{array}{l}\text { The decontamination of } \\
\text { the implant surfaces using } \\
\text { the CO2 laser combined } \\
\text { with the application of the } \\
\text { bovine bone graft showed } \\
\text { better results when } \\
\text { compared with the } \\
\text { autogenous bone graft. }\end{array}$ \\
\hline $\begin{array}{c}\text { Guler et } \\
\text { al. }^{18}\end{array}$ & $\begin{array}{l}\text { Group 1: } \\
11 \text { patients } \\
\text { Group 2: } \\
11 \text { patients }\end{array}$ & $\begin{array}{l}\text { Group } 1 \\
\text { Porous titanium granules (Natix, } \\
\text { Tigran Technologies AB, Malmö, } \\
\text { Sweden). } \\
\text { Group } 2 \\
\text { Bovine bone graft (Gen-Os, } \\
\text { OsteoBiol,Tecnoss Dental, Torino, } \\
\text { Italy). }\end{array}$ & $\begin{array}{l}\text { Control of bacterial plaque. } \\
\text { Decontamination of dental } \\
\text { implant surfaces using a } \\
\text { titanium rotating brush } \\
\text { (TiBrush, Straumann, } \\
\text { Waldenburg, Switzerland). } \\
\text { Application of biomaterials } \\
\text { to bone defects. }\end{array}$ & 6 months & $\begin{array}{l}\text { The use of titanium } \\
\text { granules due to their } \\
\text { porous structure showed } \\
\text { better results in the } \\
\text { treatment of peri-implant } \\
\text { bone defects when } \\
\text { compared to bovine bone } \\
\text { graft. }\end{array}$ \\
\hline $\begin{array}{l}\text { Roccuzz } \\
\text { o et al. }{ }^{19}\end{array}$ & $\begin{array}{l}\text { Group: } 75 \\
\text { patients }\end{array}$ & $\begin{array}{l}\text { Deproteinized bovine bone graft } \\
\text { with } 10 \% \text { collagen (Bio-Oss, } \\
\text { Geistlich Pharma, Wolhusen, } \\
\text { Switzerland). }\end{array}$ & $\begin{array}{l}\text { Control of bacterial plaque. } \\
\text { Decontamination of dental } \\
\text { implant surfaces using a } \\
\text { titanium rotating brush } \\
\text { (Tigran Peri-brush, Tigran } \\
\text { Technologies AB, Malmö, } \\
\text { Sweden). } \\
\text { Application of biomaterial } \\
\text { to bone defects. }\end{array}$ & 12 months & $\begin{array}{l}\text { The formation of a new } \\
\text { bone tissue was observed } \\
\text { radiographically, } \\
\text { confirming the } \\
\text { effectiveness of using the } \\
\text { bovine bone graft } \\
\text { deproteinized with } 10 \% \\
\text { collagen for the } \\
\text { regenerative treatment of } \\
\text { peri-implant injuries. }\end{array}$ \\
\hline $\begin{array}{c}\text { Mercado } \\
\text { et al. }^{20}\end{array}$ & $\begin{array}{l}\text { Group: } 30 \\
\text { patients }\end{array}$ & $\begin{array}{l}\text { Bovine bone graft deproteinized } \\
\text { with } 10 \% \text { collagen (Bio-Oss, } \\
\text { Geistlich Pharma, Wolhusen, } \\
\text { Switzerland) associated with } \\
\text { proteins derived from the enamel } \\
\text { matrix (EMDOGAIN, Straumann, } \\
\text { Waldenburg, Switzerland). }\end{array}$ & $\begin{array}{l}\text { Control of bacterial plaque. } \\
\text { Decontamination of dental } \\
\text { implant surfaces. } \\
\text { Application of biomaterials } \\
\text { to bone defects. }\end{array}$ & 36 months & $\begin{array}{l}\text { The regenerative treatment } \\
\text { of peri-implantitis using a } \\
\text { mixture of deproteinized } \\
\text { bovine bone graft with } \\
10 \% \text { collagen associated } \\
\text { with proteins derived from } \\
\text { the enamel matrix showed } \\
\text { positive results in the } \\
\text { treatment of peri-implant } \\
\text { injuries. }\end{array}$ \\
\hline
\end{tabular}

Source: Pinheiro et al. (2021).

\section{Discussion}

Peri-implantitis is an acute inflammatory condition caused by the accumulation of bacterial plaque, which results in bone loss around osseointegrated dental implants. Early intervention is important to improve the prognosis of peri-implant defects. Different therapeutic approaches are currently used to treat this condition. With respect to epidemiological aspects, the literature does not indicate any gender predilection and adults in their fourth to sixth decade of life are the most affected age group (Aghazadeh, 2012; Kim, 2019; Alassy, 2019). In the present study, most patients with peri-implant defects were women with a mean age of 43.2 years, corroborating literature data.

Oral hygiene instructions for the control of bacterial plaque are considered the initial treatment for peri-implantitis. Good oral health of the patient is essential to avoid recurrence of this condition. After providing oral hygiene instructions, the surface of the dental implant should be decontaminated using specific instruments such as titanium, plastic or Teflon curettes and titanium brushes in order to completely remove the granulation tissue. Alterations in the structure of the dental implant surface must be avoided as they would facilitate the colonization with microorganisms; hence, appropriate instruments should 
be used for this purpose. The application of chemical solutions and photodynamic therapy have been shown to be an effective approach to treat peri-implantitis (Schwarz, 2006; Romanos, 2008; Mercado, 2018). Guler (2017) and Roccuzzo (2016) used a rotating titanium brush for the decontamination of implant surfaces and this technique provided good results when combined with regenerative treatment using biomaterials.

Photodynamic therapy with a $\mathrm{CO} 2$ laser is considered an adjunct in peri-implantitis treatment. The photodynamic properties of the laser exert antibactericidal activity against periodontopathogenic microorganisms present at the site, increasing the potential of decontaminating peri-implant defects and stimulating bone repair (Bassetti, 2013). These findings agree with the study of Romanos (2008) in which CO2 laser application provided favorable results when combined with regenerative treatment of peri-implant defects using a bovine bone graft.

In cases of minor bone losses exposing parts of the implant surface to microbial colonization, an alternative treatment is implantoplasty (Faggion, 2014). However, in the case of large bone defects that compromise osseointegration of the dental implant, biomaterials are recommended in order to promote the formation of new bone11. Different biomaterials are being used for the regenerative treatment of peri-implantitis, including autogenous and xenogenic bone grafts; however, other biomaterials are gaining space such as porous titanium granules and hydroxyapatite (Schwarz, 2006; Aghazadeh, 2012; Guler, 2017).

The most important features of a biomaterial used for bone regeneration are related to its osteogenic, osteoconductive and osteoinductive capacities. Within this context, hydroxyapatite is known for its high osteoconductivity resulting from the chemical interaction with osteogenic cells and the local environment. The combination of this biomaterial with titanium improves its capacity of bone-implant integration, favoring better osseointegration (Xu, 2018). Schwarz (2006) compared the use of nanocrystalline hydroxyapatite and bovine bone graft. Both biomaterials induced new bone formation. However, inferior results were observed for hydroxyapatite. This finding might be explained by the low osteogenic potential of hydroxyapatite when compared to xenogenic grafts.

The studies of Romanos (2008) and Aghazadeh (2012) compared autogenous and bovine bone grafts for the treatment of peri-implant defects. The latter provided higher bone-defect fill than autogenous grafts. The results are related to the high osteoconductive capacity and low reabsorption rate of xenogenic grafts by the organism.

Guler (2017) compared bovine bone graft and porous titanium granules for the treatment of peri-implant bone defects and observed that the latter provided better results than the xenogenic graft. These findings are related to the properties of titanium granules. These granules are composed of pure non-resorbable titanium which, when mixed with blood or saline, bond together to form an integral structure, activating the complement system and establishing a connection with the platelet surface. Platelet-derived growth factor is an osteogenic cytokines that plays a key role in bone production. Thus, in addition to bone-defect filling, this biomaterial also promotes osteoconductive activity.

All studies selected for the present systematic review used some type of bovine bone graft. Xenogenic grafts were found to yield excellent outcomes in the treatment of peri-implant defects, particularly due to their osteoconductive effects. Mercado (2018) used a combination of deproteinized bovine bone mineral with $10 \%$ collagen and enamel matrix protein derivative. These proteins derived from the process of odontogenesis induce undifferentiated mesenchymal cells to initiate periodontal neoformation and, consequently, the production and differentiation of bone cells. The combination of xenografts and enamel matrix derivative provided promising results in peri-implant bone regeneration.

\section{Conclusion}

The studies demonstrated that the initial therapeutic approach to peri-implantitis consisting of plaque control and implant surface decontamination and subsequent surgery for the placement of biomaterials were essential for the success of 
regenerative treatment of peri-implant defects. Analysis of all biomaterials used for surgical regenerative treatment of periimplantitis included in this systematic review showed that bovine bone grafts yielded superior outcomes in terms of bone neoformation in peri-implant defects when compared to autogenous grafts and nanocrystalline hydroxyapatite. In addition, deproteinized bovine bone mineral with $10 \%$ collagen combined with enamel matrix protein derivative provided the most promising long-term outcomes among the xenografts studied, as demonstrated by the absence of recurrence of peri-implant defects after a follow-up of 36 months.

It is important to note that porous titanium granules have emerged as a promising biomaterial for the regenerative treatment of peri-implantitis, providing superior outcomes compared to bovine bone grafts in terms of defect filling and gain in clinical attachment. Biomaterials are promising for the treatment of peri-implant bone defects and the number of in silico biomaterials that can provide treatment of excellence to patients with this condition is expected to increase in the near future.

\section{References}

Alassy, H. (2019) Peri-Implantitis Diagnosis and Prognosis Using Biomarkers in Peri-Implant Crevicular Fluid: A Narrative Review. Diagnostics (Basel). 9(4): 214.

Alqahtani, F. (2019) Self-rated peri-implant oral symptoms and clinicoradiographic characteristics in Narghile-smokers, cigarette-smokers, and nonsmokers with peri-implantitis. Clin Implant Dent Relat Res. 21(6): 1235-1240.

Aghazadeh, A. (2012) A single-centre randomized controlled clinical trial on the adjunct treatment of intra-bony defects with autogenous bone or a xenograft: results after 12 months. J Clin Periodontol. 39(7): 666-673.

Arab, H. (2016) Comparison of Two Regenerative Surgical Treatments for Peri-Implantitis Defect using Natix Alone or in Combination with Bio-Oss and Collagen Membrane. J Long Term Eff Med Implants. 26(3): 199-2014.

AAP, American Academy of Periodontology. (2013) Peri-implant mucositis and peri-implantitis: a current understanding of their diagnoses and clinical implications. J Periodontol. 84: 436-443.

Bassetti, M. Anti-infective therapy of periimplantitis with adjunctive local drug delivery or photodynamic therapy: 12-month outcomes of a randomized controlled clinical trial. Clin Oral Implants Res. 25(3):279-287.

Faggion, C. (2014) A systematic review and Bayesian network meta-analysis of randomized clinical trials on non-surgical treatments for peri-implantitis. $J$ Clin Periodontol. 41(10): 1015-1025.

Guler, B. The comparison of porous titanium granule and xenograft in the surgical treatment of peri-implantitis: a prospective clinical study. Clin Implant Dent Relat Res. 19(2): 316-327.

Heitz-Mayfield, L. (2014) The therapy of peri-implantitis: a systematic review. Int J Oral Maxillofac Implants. 29:325-345.

Higgins J, \& on behalf of the Cochrane Statistical Methods Group (2011). Chapter 8: Assessing risk of bias in included studies. In J. P. T. Higgins, \& S. Green (Eds.), Cochrane handbook for systematic reviews of interventions Version 5.1.0, March 2011.

Kim, J. (2019) Biological Responses to the Transitional Area of Dental Implants: Material- and Structure-Dependent Responses of Peri-Implant Tissue to Abutments. Materials (Basel). 13(1): 72.

Mccrea, S. (2014) Advanced peri-implantitis cases with radical surgical treatment. J Periodontal Implant Sci. 44(1): 39-47.

Mercado, F. (2018) Regenerative surgical therapy for peri-implantitis using deproteinized bovine bone mineral with $10 \%$ collagen, enamel matrix derivative and Doxycycline-A prospective 3-year cohort study. Clin Oral Implants Res. 29(6):583-591.

Moher, D. (2009) PRISMA Group. Preferred reporting items for systematic reviews and meta-analyses: the PRISMA statement. PLoS Med. 21;6(7): e1000097.

Noriko, M. (2014) Intraindividual variation in core microbiota in peri-implantitis and periodontitis. Sci Rep. 4(6602):1-10.

Lopes, D. (2018) Bone physiology as inspiration for tissue regenerative therapies. Biomaterials. 185: 240-275.

Roccuzzo, M. (2016) Surgical therapy of single peri-implantitis intrabony defects, by means of deproteinized bovine bone mineral with $10 \%$ collagen. $J$ Clin Periodontol. 43(3): 311-318.

Romanos, G. (2008) Regenerative therapy of deep peri-implant infrabony defects after CO2 laser implant surface decontamination. Int J Periodontics Restorative Dent. 28(3): 245-255.

Roos-Jansaaker, A. (2014) Surgical treatment of periimplantitis using a bone substitute with or without a resorbable membrane: a 5-year follow-up. $J$ Clin Periodontol. 41(11): 1108-1114. 
Research, Society and Development, v. 10, n. 12, e275101220454, 2021

(CC BY 4.0) | ISSN 2525-3409 | DOI: http://dx.doi.org/10.33448/rsd-v10i12.20454

Rotenberg, S. (2016) Collagen-Coated Bovine Bone in Peri-implantitis Defects: A Pilot Study on a Novel Approach. Int J Oral Maxillofac Implants. 31(3):701-707.

Schwarz, F. (2006) Healing of intrabony peri-implantitis defects following application of a nanocrystalline hydroxyapatite (Ostim) or a bovine-derived xenograft (Bio-Oss) in combination with a collagen membrane (Bio-Gide). A case series. J Clin Periodontol. 33(7): 491-499.

Xu, Y. (2018) Polydopamine-induced hydroxyapatite coating facilitates hydroxyapatite/polyamide 66 implant osteogenesis: an in vitro and in vivo evaluation. Int J Nanomedicine. 13: 8179-8193.

Wiltfang, J. (2012) Regenerative treatment of peri-implantitis bone defects with a combination of autologous bone and a demineralized xenogenic bone graft: a series of 36 defects. Clin Implant Dent Relat Res. 14(3): 421-427. 